\section{Vaginal Yeasts and the Antifungal Action of Red Propolis Extract}

\title{
Abstract
}

Introduction: Vulvovaginitis is an inflammatory process that affects the vulva, vagina and cervix, most of the times of infectious cause. Vulvovaginal candidiasis is the second most frequent cause in Brazil, in Europe ranks first. Candida spp can be found in the vagina up to $20 \%$ of asymptomatic women.

Objective: Understanding the occurrence of vaginal yeasts and evaluating the antifungal action of a red propolis extract.

Method: This is a clinical study in vitro with vaginal secretion samples collected from 197 patients treated at the Health Center Frei Damiao in Patos-PB, Brazil. The species were identified using a chromogenic medium $\mathrm{CHROMagar}$ Candida ${ }^{\circledR}$. At the end, the antifungal activity of the red propolis extract in four different concentrations was observed: $25 \%, 50 \%, 75 \%$ and $100 \%$, by test disc Agar diffusion. The study was approved by the Research Ethics Committee of the Federal University of Campina Grande, CAAE 35203614.8.0000.5575.

Results: Of the samples analyzed other species identified by the medium used were the most prevalent corresponding to $59.8 \%$, followed by C. albicans, with $21.7 \%$. The antifungal activity was observed in $81.25 \%$ of the tested samples. According to the average and standard deviation of the inhibition zone of the four concentrations, the one that presented the smallest variation was the concentration at $50 \%$, followed by concentration to $75 \%$.

Conclusions: The results of this research showed that there was antifungal action of red propolis extract, since occurred inhibition in $81.25 \%$ of the analyzed samples. However did not show clearance regarding this action, since positivity tendency was not growing by increasing or decreasing the concentration of propolis extract.

Kévia Katiúcia Santos Bezerra', Maria do Carmo Andrade Duarte de Farias ${ }^{1}$, Patrício Borges Maracajá2, Alfredina dos Santos Araújo², Rosilene Agra da Silva $^{2}$, Antônio Fernandes Filho ${ }^{3}$, Anne Milane Formiga Bezerra ${ }^{4}$, Aucelia Cristina Soares de Belchior ${ }^{5}$, Francisco Alírio da Silva ${ }^{1}$, Cláudia Sarmento Gadelha1, Wilma Kátia Trigueiro Bezerra6 ${ }^{6}$, Joyce Carolle Bezerra Cavalcante ${ }^{7}$

1 Federal University of Campina Grande. Academic Unit of Life Sciences, Teacher training center, Cajazeiras, Paraíba, Brazil.

2 Federal University of Campina Grande. Graduate-degree in Agroindustrial Systems, Pombal, PB, Brazil.

3 Federal University of Campina Grande. Academic Unit of Nursing, Teacher training center, Cajazeiras, Paraíba, Brazil.

4 Nurse in a Mobile Emergency Service, MSU, Sousa, Paraíba, Brazil.

5 Teacher of Faculty Santa Maria, Cajazeiras, Paraíba, Brazil; and Faculties Integrated of Patos, PB, Brazil.

6 Nurse in a Mobile Emergency Service, MSU, Paulista, PB, Brazil.

7 Federal University of Campina Grande. Student of Medicine, Academic Unit of Life Sciences, Cajazeiras, Paraíba, Brazil.

\section{Contact information:}

Maria do Carmo Andrade Duarte de Farias

झ keviabezerra@gmail.com

Keywords

Propolis; Candida; Vulvovaginitis; Products with antimicrobial action. 


\section{Introduction}

The vulvovaginal candidiasis (VVC) is an infection characterized by white, odorless vaginal morbid discharge, associated with vulvar and vaginal lesions, itching and burning. It affects more often pregnant patients, diabetic and who used antibiotics. Diagnosis is based on signs and symptoms and laboratory tests [1].

The therapy for this infection is restricted, limited to the polyene and azole. Nystatin has been used for decades; however therapeutic failures were observed [2-3]. Of the azole fluconazole is one of the most widely used; however, has shown the occurrence of strains with decreased sensitivity, and other resistant in vivo and in vitro, to certain antifungal agents, side effects and high recurrence rates $[1,4]$.

In view of this, the natural products have been traditionally used in the treatment of diseases, because they are sources of many actives, and these are the basis for the vast majority of anti-infective therapies in current clinical in use [5].

Thus, propolis is a natural product, of a resinous aspect, variable chemical composition, collected from various plant species by honey bees that add salivary secretions; being considered an organotherapic, which means product obtained from glands, organs, tissues and animal secretions [6].

Propolis is a complex mixture composed of balsamic resin material, collected by honey bees from flowers, plant exudates or other parts of the plant tissue plus wax, pollen and products of their metabolism, as the enzyme salivary $\beta$-glycosidase, responsible for the hydrolysis of flavonoid glycosides in aglucones increasing its pharmacological action [7].

In Brazil, biological properties and different chemical compositions are described for samples collected in different regions of the country. This variation can be explained by the Brazilian biodiversity [6] The Brazilian propolis was identified and classified into 12 main groups, according to geographic re- gion of origin and the vegetation from which it was extracted the chemical composition [8].

Recently, a new group of Atlantic Forest in the States of Alagoas, Paraiba, Pernambuco, Bahia and Sergipe was ranked as the $13^{\text {th }}$ type of Brazilian propolis, called red propolis. It had its botanical origin identified as Dalbergia ecastophyllum (L) Taub, known popularly as Bugiu-of-Tail, a species of legume with different physical and chemical characteristics of other samples from 12 groups, and has a potent biological action [9-10]. This biological potential of this natural product is due to a synergism that occurs between its many components [11]. In addition, the Brazilian propolis is known for its antifungal activity [12].

Moreover, the interest of researchers from around the world has been awakened to use propolis, especially, its therapeutic properties: antimicrobial, anti-inflammatory, immunomodulatory, antioxidant, antitumor and antiviral [13].

The ability of propolis to inhibit the growth of microorganisms is the pharmacological activity more popularly known and scientifically proven [14]. Considering that the Brazilian propolis has been the subject of intensive research in recent decades, this research aimed to identify, in women attending in a gynecology clinic of the countryside of Paraiba (Brazil), vaginal yeasts and the antifungal activity of red propolis extract.

\section{Material and Method}

This is a clinical study in vitro with vaginal secretion samples collected from 197 patients treated at Health Center Frei Damião, in the municipality of Patos-PB (Brazil), in the period from July to November 2014. The patients agreed to participate in the research, by clarifying and signing of the Informed Consent. In compliance with Resolution 466/12, the research was approved by the Research Ethics Committee of the Federal University of Campina Grande, CAAE 35203614.8.0000.5575 protocol. 
Gynecological examination was performed to speculate, for the purpose of collecting vaginal discharge using swuab (culture swuab transport system - COPAN). Samples of vaginal secretions were obtained from collections recommended previously [1516]. Analyses were performed in the Microbiology Laboratory Technological Vocation Center, Federal University of Campina Grande, campus of Pombal, Paraíba. The material was seeded onto plates containing Sabouraud Agar (Sabouraud Dextrose Agar - Difco). The plates were incubated at $37^{\circ} \mathrm{C}$ for 72 hours. After this period the reading was performed and checked the growth of Candida colonies characteristics. The identification takes place through the study of macroscopic and biochemical aspects Chrom Agar Candida® (Probac Brazil), a means of chromogen culture that allows identifying presumptive action of yeasts, because it contains several enzymatic substrates hydrolyzed by the corresponding hexoaminidases allow to identify action yeast according to the colony pigmentation displayed in a time of 24 to 48 hours [17]. The medium used indicates green colonies, for $C$. albicans; Rugose Rose for $C$. krusei; metallic blue, for C. tropicalis; white and violet, for other species. The reading of the plates and the interpretation of results were carried out by observing the morphology and pigmentation of the colonies [18].

The red propolis samples were obtained from a beekeeper from the coast of Paraíba of Apis mellife- ra bees arising from the Dalbergi frutescens (Bugiuof-Tail), in which the statement was made to $30 \%$ of ethyl alcohol PA [10]. The antifungal activity of the propolis extract was analyzed in four different concentrations: $100 \%, 75 \%, 50 \%$ and 25\% (dilution ethyl alcohol 70\%) and was determined by the Agar diffusion test, in which samples of Candida were grown on Sabouraud agar and incubated at $37^{\circ} \mathrm{C} / 48 \mathrm{~h}$. Then, filter paper discs were soaked used with $10 \mu \mathrm{L}$ extract at the concentrations and deposited on the surface of Sabouraud agar containing the colonies of Candida sp. The plates were incubated at $37^{\circ} \mathrm{C} / 48 \mathrm{~h}$. After it the measurement was made with a caliper, of the halos of inhibition of Candida growth. From the results, it was considered active product against the species of the microorganisms under study which produced halos that above 10 $\mathrm{mm}$ in diameter [19].

\section{Results}

\section{Vaginal secretion: species of Candida identified}

The results of vaginal culture of 197 participants showed that $46.2 \%(n=91)$ were positive for some species of Candida. Noting that, in a sample, there were identified two species and the patient was asymptomatic. The data in Table 1 show the species identified in samples whose culture was positive. By

Table 1. Species of Candida identified in the samples of culture of vaginal secretion $(n=91)$.

\begin{tabular}{|l|c|c|}
\hline Species of Candida & $n$ & $\%$ \\
\hline Other species* & 55 & 59.8 \\
\hline C. albicans & 20 & 21.7 \\
\hline C. tropicalis* & 15 & 16.3 \\
\hline C. krusei & 2 & 2.2 \\
\hline
\end{tabular}

Source: Research data. Patos-PB, 2014.

* In a sample there were identified two species (C. tropicalis and Other species) 
those findings, prevailed for other species unidentified culture medium with $59.8 \%(n=55)$, followed by the species $C$. albicans, with $21.7 \%(n=20)$ and of C. tropicalis with $16.3 \%(n=15)$.

It was noticed by the findings that the percentage of symptomatic women $85 \%(n=17)$ was higher in the kind of C. albicans, compared to $53.52 \%$ ( $n=$ 38) of species other than albicans. (Data not shown in table).

In table 2, divided the groups of species of Candida in C. albicans and non-albicans, there are presented according to age and characteristics of the menstrual cycle of the women interviewed. It appears that the percentage of $C$. albicans species $37.5 \%$ was higher in younger women, compared to the lowest percentage of this kind $4.7 \%$ in women of higher age, demonstrating statistical dependence between variables ( $p=0.001)$ since by increasing the age of women it was reduced the percentage of species C. albicans and increased of the non-albicans. Moreover, the variables of species of Candida and menstrual cycle characteristics did not show statistically dependence ( $p=0.122)$, although there was a tendency to increase the percentage of $C$. albicans in women with menstrual cycles present. (Table 2)

\section{Antifungal action of red propolis extract}

Of the 91 vaginal secretion samples with the presence of Candida, only 48 samples formed fungal growth with the number of colonies sufficient to conduct the inhibition test with extracts of propolis, according to the method used for this purpose.

When testing the antifungal action of red propolis extract on 48 samples referred to, it was noticed that in $81.25 \%$ ( $n=39$ ) the result was positive, forming halo of inhibition higher than $10 \mathrm{~mm}$. However, the positive antifungal action prevailed in 95\% ( $n=19 / 20$ ) on C. albicans, followed by $87.5 \%$ in C. tropicalis $(n=7 / 8)$ (Table 3 ).

Facing the different extract concentrations of red propolis, added to samples with identification of Candida species, it was possible to identify variations of 12 to $100 \mathrm{~mm}$ in positivity of antifungal action, considering that this action is only proven in the presence of halo of inhibition greater than $10 \mathrm{~mm}$. Thus, Table 4 shows that, according to the average and standard deviation of the inhibition halo of the four concentrations, presented the lowest change was the concentration at $50 \%$, followed by concentration to $75 \%$.

Table 2. Distribution of species of Candida according to age and characteristics of the menstrual cycle of the interviewed.

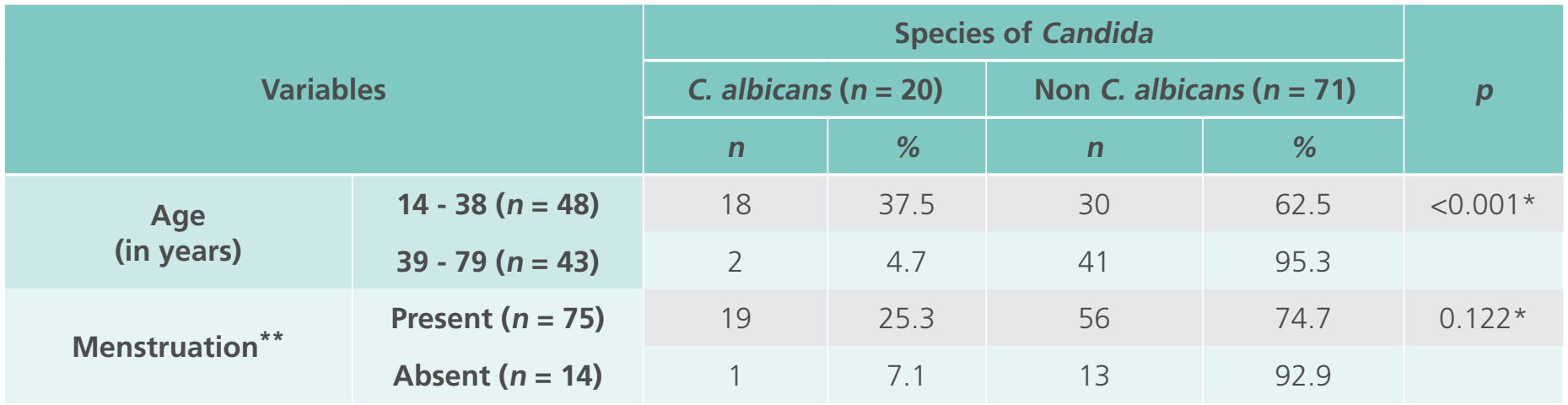

Source: Research data. Patos-PB, 2014.

$p$ - Chi-square Test $\left(X^{2}\right)$ or * Fisher Exact Test; Statistical significance if $p<0.05$.

${ }^{*}$ Excluded two hysterectomized. 
Table 3. Distribution of species of Candida identified in the culture of vaginal secretion, according to the antifungal action of red propolis extract $(n=48)$.

\begin{tabular}{|c|c|c|}
\hline \multirow{2}{*}{ Species of Candida } & \multicolumn{2}{|c|}{ Positive } \\
\hline & $n$ & $\%$ \\
\hline C. albicans $(n=20)$ & 19 & 95.0 \\
\hline C. tropicalis $(n=08)$ & 7 & 87.5 \\
\hline Other species $(n=18)$ & 12 & 66.7 \\
\hline C. krusei $(n=2)$ & 1 & 50.0 \\
\hline
\end{tabular}

Source: Research data. Patos-PB, 2014.

The data shown in Table 4 indicate that the lowest and highest number of cases of positive antifungal action, respectively, were found at a concentration of $100 \%(n=17)$ and $25 \%(n=35)$. This association was not observed in the average positive aspects of mergers, as the lowest average/standard deviation difference was found in the concentration to $50 \%$. Thus, considering the greater appearance of inhibition zones, there are indications that the lowest concentration of propolis extract has a higher antifungal action.

It is also noticed that although there was total inhibition $(100 \mathrm{~mm})$ in a sample tested at a concentration of $100 \%$, the concentration with the highest quantity of positivity in the samples tested was $25 \%$ (87.2\% $n=35 / 39)$, with inhibition zones ranging from 12 to $80 \mathrm{~mm}$; and the positivity of 20,30 , 40 and $50 \mathrm{~mm}$ were observed at all concentrations.

(Table 4)

\section{Discussion}

Fungal vulvovaginitis is caused predominantly by the genus Candida, being $C$. albicans the most prevalent. But actually there has been an increase in species non-albicans, in some populations. The greatest concern lies in the fact that these other species, in general, tend to be more resistant to antifungal agents [20-21].

It is estimated that about $75 \%$ of adult women have at least one episode of fungal VVC in their life. Of these, 40 to $50 \%$ experience further outbreaks and $5 \%$ become applicants. On the other hand, studies indicate that $20-25 \%$ of asymptomatic healthy women and have positive cultures of vaginal discharge for yeast and that among the colonized patients, about $50 \%$ present VVC at some point in their life [20, 22].

About 80 to $90 \%$ of cases of VVC are due to species C. albicans and 10 to $20 \%$ of the species non-albicans (C. tropicalis, C. glabrata, C. krusei, C. parapsilosis, C. pseudotropicalis, C. lusitaniae) [23]. However, studies show that, in some populations, the frequency of isolation of yeasts non-C. albicans has increased [20].

Other authors have also observed the predominance of non-albicans species. In a study with 4.228 Italian women met in gynecology services found a higher prevalence of non-albicans, 57.2\% [24]. Similar in another study involving 44 women with candidiasis history, they found $40.91 \%$ of positive cultures for Candida spp and of these, identified $52.63 \%$ of non- C.albicans [25]. 
Table 4. Results of antifungal action of red propolis extract in concentrations to $100 \%, 75 \%, 50 \%$ and $25 \%(n=39)$.

\begin{tabular}{|c|c|c|c|c|}
\hline \multirow[b]{2}{*}{ Results (mm) } & \multicolumn{4}{|c|}{ Concentrations of propolis extract } \\
\hline & $\begin{array}{c}100 \% \\
(43.6 \% n=17)\end{array}$ & $\begin{array}{c}75 \% \\
(53.8 \% n=21)\end{array}$ & $\begin{array}{c}50 \% \\
(51.3 \% n=20)\end{array}$ & $\begin{array}{c}25 \% \\
(89.7 \% n=35)\end{array}$ \\
\hline Average (SD) & $40.00 \pm 22.492$ & $30.00 \pm 13.684$ & $27.7 \pm 11.973$ & $30.00 \pm 18.991$ \\
\hline Minimum-Maximum & $20-100$ & $15-60$ & $20-50$ & $12-80$ \\
\hline $12 \mathrm{~mm}$ & - & - & - & $2.9 \%(=1)$ \\
\hline $15 \mathrm{~mm}$ & - & $14.3 \%(=3)$ & - & $8.6 \%(=3)$ \\
\hline $20 \mathrm{~mm}$ & $41.2 \%(=7)$ & $28.6 \%(=6)$ & $45.0 \%(=9)$ & $20.0 \%(=7)$ \\
\hline $21 \mathrm{~mm}$ & - & - & - & $2.9 \%(=1)$ \\
\hline $23 \mathrm{~mm}$ & - & - & - & $2.9 \%(=1)$ \\
\hline $25 \mathrm{~mm}$ & - & - & $5.0 \%(=1)$ & $2.9 \%(=1)$ \\
\hline $28 \mathrm{~mm}$ & - & - & - & $2.9 \%(=1)$ \\
\hline $30 \mathrm{~mm}$ & $5.9 \%(=1)$ & $19.0 \%(=4)$ & $20.0 \%(=4)$ & $14.3 \%(=5)$ \\
\hline $35 \mathrm{~mm}$ & - & - & - & $2.9 \%(=1)$ \\
\hline $40 \mathrm{~mm}$ & $5.9 \%(=1)$ & $19.0 \%(=4)$ & $10.0 \%(=2)$ & $14.3 \%(=5)$ \\
\hline $50 \mathrm{~mm}$ & $23.5 \%(=4)$ & $14.3 \%(=3)$ & $20.0 \%(=4)$ & $11.4 \%(=4)$ \\
\hline $60 \mathrm{~mm}$ & $17.6 \%(=3)$ & $4.8 \%(=1)$ & - & $5.7 \%(=2)$ \\
\hline $80 \mathrm{~mm}$ & - & - & - & $8.6 \%(=3)$ \\
\hline $100 \mathrm{~mm}$ & $5.9 \%(=1)$ & - & - & - \\
\hline
\end{tabular}

Source: Research data. Patos-PB, 2014.

Regarding the Candida species found in the sample investigated (Table 1), it is known that up to $40 \%$ of women may have one or more species, as constituent of the vaginal flora without symptoms [26]. Other researchers believe that most vulvovaginitis is caused by a single species of Candida. However two or more species may be involved simultaneously [27].

Following the increasing trend of Candida nonalbicans species, this study showed a predominance of these, corresponding to $78.3 \%$ of the species (Table 1). The reasons for this increase in non-albicans species, over the years, are the inappropriate use of topical and systemic antifungal once more select species resistant to antifungal agents most widely used. Studies have linked the emergence of C. albicans species not to the use of fluconazole [28- 29].

In turn, researchers [30] reported that the erroneous, inappropriate or incomplete use of antifungals would enable the elimination of $C$. albicans most sensitive species, selecting the most resistant non-albicans. Furthermore, it is reported that various antifungal agents such as clotrimazole, ketoconazole, miconazole, nystatin, butoconazole, are not active in vitro or in vivo against non-albicans species 
[30-31]. However, other factors can contribute: the geographical location, the characteristics of the studied populations and other inherent in the diagnosis $[20,27]$. Since non-albicans species show a significant association with absence of symptoms [32].

Several authors associated the presence of symptoms with the isolation of $C$. albicans and other species, to the absence of symptoms [32]. A study with 223 samples identified Candida spp in 31\% of symptomatic women and in $8 \%$ of asymptomatic women; and non-albicans species corresponded to $33 \%$ of asymptomatic group and $13 \%$ of symptomatic [33].

Regarding the association between the presence of Candida and the age of the participants recently survey did not observe this relationship, since the average age of cultures positive for Candida was 37 years old, ranging from 14 to 65 years old [34]. Other research found that the higher frequency of patients with positive cultures was between 14 and 46 , and showed no association between the identified species of yeast and the age of the patients [35].

Regarding the menstrual cycle it was observed that when regular, was significantly associated with vulvovaginal candidiasis; and explained that it is possible that estrogen peaks facilitate fungal invasion of the vaginal mucosa [36].

The presence of regular menstrual cycles have been identified as relevant, since the acidity subsequent to hormone peaks of $\mathrm{FSH}$, LH, estradiol and progesterone may contribute to the invasion of the vaginal mucosa [33]. Moreover, it is possible to relate the high levels of estrogen and a positive culture for Candida. It is believed that, due to higher estrogen levels, the incidence of symptoms is higher in women of reproductive age [35].

About antifungal action of propolis extract, verified in this study, other researchers also found such action on different Candida species in sensitivity following order: C. albicans > C. tropicalis > C. krusei $>$ C. guilliermondii [37].
Several studies have demonstrated the action of propolis on yeast, especially on C. albicans $[12,38]$. Despite the differences in propolis composition studies at different times and in different regions demonstrated their antifungal activity [39-40].

Comparing the activities of propolis and fluconazole against Candida spp isolated from the mouths of HIV-positive patients, researchers found that propolis extract was able to inhibit the yeast with a minimum inhibitory concentration (MIC) less than fluconazole [41]. Propolis also showed antifungal activity against dermatophytes $C$. neoformans and onychomycosis and exhibited a synergistic effect with macrophages against Paracoccidioides brasiliensis.

Some research found that the ethanol extract of propolis has fungistatic activity at a concentration of $0.55 \mathrm{mg} / \mathrm{ml}$ [42]. Other studies have demonstrated fungicidal activity at concentrations of 3 to $7 \mathrm{mg} /$ $\mathrm{ml}$, being more susceptible species $C$. albicans [43].

This difference is due to different strains analyzed because researchers gave the antifungal potential of propolis in asymptomatic and symptomatic patients, compared to Nystatin, which obtained positive results before the vulvovaginal candidiasis [44].

Moreover, it can still be related to the isolation site and also the virulence of the agent in question, since studies underscore the yeast's ability to adhere to infect and cause disease by its potential virulence and pathogenicity, determined by virulence factors expressed genetically, when subjected to certain situations [45].

An in vivo study in Paraná noted that the propolis extract has shown activity similar to Nystatin, with inhibition profile of the vaginal infection by different Candida species [46]. The antifungal and antibacterial activities of propolis are attributed mainly to pinocembrine flavonona, the galargina flavonol and phenylethyl ester of caffeic acid, substances whose mechanism of action is probably in inhibiting bacterial RNA polymerase [47]. The compounds flavonoids, caffeic acid, cinnamic acid and benzoic acid, 
probably acting on the wall or cell membrane of microorganisms, causing structural damage [13].

\section{Conclusion}

Despite the antifungal action of propolis extract, with inhibition in $81.25 \%$ of the samples analyzed, it appears that, although the most effective concentration was $25 \%$ for all other concentrations also observed antifungal action, especially considering that there were different strains in different patients, with varied responses due to particularities.

The positive trend of antifungal action of red propolis extract was not increased by increasing or decreasing the concentration of propolis extract. Therefore, such studies are relevant because of the need for new therapeutic alternatives, especially low-cost, more efficient and safe for the treatment of vulvovaginal candidiasis, considering the few treatment options available and the observed resistance of Candida to some usual drugs.

\section{References}

1. Dalazen D, Zanrosso D, Wanderley L, Silva NL, Fuentefria AM. Comparação do perfil de suscetibilidade entre isolados clínicos de Candida spp. orais e vulvovaginais no Sul do Brasil. J Bras Patol Med Lab [Internet]. 2011 Feb; 47(1): 33-8. Available from: <http://www.scielo.br/pdf/jbpml/v47n1/04.pdf>. doi: http:// dx.doi.org/10.1590/S1676-24442011000100004

2. Consolaro ME, Albertoni TA, Svidzinski $A E$, Peralta RM, Svidzinski TI. Vulvovaginal Candidasis is associated with the production of germ tubes by Candida albicans. Mycopathologia [Internet]. 2005 Jun; 159(4):501-7. Available from: <http://www.ncbi.nlm. nih.gov/pubmed/15983735>. doi: http://dx.doi.org/10.1007/ s11046-005-1149-0. PubMed PMID: 15983735.

3. Dota KFD, Shinobu CS, Patussi EV, Consolaro MEL, Svidzinski TIE. Susceptibility to vaginal yeast in most used antifungical in Maringá, Paraná, Brazil. Acta Bioquim Clin Latinoam [Internet]. 2008 Oct; 110:66-72. Available from: <http://www.scielo.org. ar/pdf/abcl/v42n4/v42n4a08.pdf>
4. Nunes LCC, Lima MAR, Sousa KMH, Prado AIO, Soares-Sobrinho $J \mathrm{~L}$, Rolim-Neto PJ. Desenvolvimento de gel vaginal contendo extrato de própolis vermelha. Rev Bras Farm [Internet]. 2012; 93(2): 179-85. Available from: <http://www.rbfarma.org.br/ files/rbf-2012-93-2-8.pdf>

5. Butts A, Krysan DJ. Antifungal drug discovery: something old and something new. PLOS Pathogens [Internet]. 2012 Sep; 8(9). Available from: <http://www.ncbi.n/m.nih.gov/pmc/articles/ PMC3435257/>. doi: http://dx.doi.org/ http://www.ncbi.nlm. nih.gov/pmc/articles/PMC3435257/. PubMed Central PMCID: PMC3435257.

6. Portilho DR, Melo IA, Guerra RC, Batista $H L$, Fernandes $C H C$. Avaliação da atividade antibacteriana e antifúngica da própolis produzida no estado do Tocantins. Rev Cient do ITPAC [Internet]. 2013 Apr; 6(2). Available from: <http://www.itpac.br/arquivos/ Revista/62/1.pdf>

7. Oliveira KAM, Oliveira GV, Batalini C, Rosalem JA, Ribeiro LS. Atividade antimicrobiana e quantificação de flavonoides e fenóis totais em diferentes extratos de própolis. Semina: Ciênc Biol Saúde [Internet]. 2012 Jul/Dec; 33(2): 211-22. Available from: <http://www.uel.br/revistas/uel/index.php/seminabio/article/ view/10827/12168>. doi: http://dx.doi.org/10.5433/16790367.2012v33n2p211

8. Park YK, Ikegaki M, Alencar SM. Evaluation of brazilian propolis by both physicochemical methods and biological activity. Honeybee Science [Internet]. 2000; 21(2): 85-90. Available from: <http://www.cabdirect.org/abstracts/20000508894.htm l;jsessionid=257A25DA65F7139693018667252A362F>.

9. Batista LLV, Campesatto EA, Assis MLB, Barbosa APF, Grillo LAM, Dornelas CB. Estudo comparativo do uso tópico de própolis verde e vermelha na reparação de feridas em ratos. Rev Col Bras Cir [Internet]. 2012 Nov/Dec; 39(6): 515-20. Available from: <http://www.scielo.br/scielo.php?pid=\$010069912012000600012\&script=sci_arttext>. doi: http://dx.doi. org/10.1590/S0100-69912012000600012

10. Daugsch A, Moraes CS, Fort P, Pacheco E, Lima IB, Abreu JA, et al. Própolis vermelha e sua origem botânica. Mensagem Doce [Internet]. 2006; 89: 2-8. Available from: <http://http://www. apacame.org.br/mensagemdoce/89/artigo.htm>.

11. Krol W, Schller S, Czuba Z, Matsuno T, Zydowicz G, Shani J, et al. Inhibition of neutrophils' chemiluminescence by ethanol extract of propolis (EEP) and its phenolic components. J of Ethnopharmacology [Internet]. 1996 Dec; 55: 19-25. Available from: $\quad<$ http://www.ncbi.nlm.nih.gov/pubmed/9121163>. PubMed PMID: 9121163

12. Oliveira AC, Shinobu CS, Longhini R, Franco SL, Svidzinski TI. Antifungal activity of propolis extract against yeasts isolated from onychomycosis lesions. Mem Inst Oswaldo Cruz [Internet]. 
2006 Aug; 101(5): 493-7. Available from: <http://www.scielo. br/pdf/mioc/v101n5/v101n5a02.pdf>. doi: http://dx.doi. org/10.1590/S0074-02762006000500002. PubMed PMID: 17072451

13. Scazzocchio F, D'Auria FD, Alessandrini D, Pantanella F. Multifactorial aspects of antimicrobial activity of propolis. Microbiol Res [Internet]. 2006 Jan; 161(4): 327-33. Available from: $\quad<$ http://www.sciencedirect.com/science/article/pii/ S0944501305001230>. doi: http://dx.doi.org/10.1016/j. micres.2005.12.003. PubMed PMID: 16427259.

14. Bastos EMAF, Santana RA, Calaça-Costa AGF, Thiago PS. Interaction between Apis melliferaL and Baccharis dracunculifolia $D C$, that favours green propolis production in Minas Gerais. Braz J Biol [Internet]. 2011 Aug; 71(3): 727-34. Available from: <http://www.scielo.br/scielo.php?pid=S151969842011000400018\&script=sci_arttext>. doi: http://dx.doi. org/10.1590/S1519-69842011000400018

15. Lacaz CS, Porto E, Martins JEC, Heins-Vaccari EM, Takahashi MN.Tratado de micologia médica. São Paulo: Sarvier; 2002. 9 ed. São Paulo: Sarvier; 2002.

16. Sidrim JJC, Rocha MFG. Micologia médica a luz de autores contemporâneos. Rio de Janeiro: Guanabara Koogan; 2004.

17. Quindós G, Alonso-Vargas R, Helou S, Arechavala A, MartínMazuelos E, Negroni R. Evaluación de un nuevo medio de cultivo cromógeno (Candida ID) para el aislamiento e identificación presuntiva de Candida albicans y otras levaduras de interés médico. Rev Iberoam Micol [Internet]. 2001; 18: 23-8. Available from: $<$ http://www.reviberoammicol.com/2001-18/023028.pdf>

18. Odds FC, Bernaerts R. CHROMagar Candida, a new differential isolation medium for presuntive identification of clinically important Candida species. J Clin Microbiol [Internet]. 1995 Aug; 32(8): 1923-9. Available from: <http://www.ncbi.nlm.nih. gov/pmc/articles/PMC263904/>. doi: http://dx.doi.org/10.1128/ JCM.39.5.2015-2016.2001. PubMed PMID: PMC88073.

19. Duarte S, Koo H, Bowen WH, Hayacibara MF, Cury JA, Ikegaki $M$, Rosalen PL. Effect of a novel type of propolis and its chemical fractions on glucosyltransferases and on growth and adherence of mutans streptococci. Biol Pharm Bull [Internet]. 2003 Apr; 26(4):527-31. Available from: <http://www.ncbi.nlm.nih.gov/ pubmed/12673037>. PubMed PMID: 12673037.

20. Ferrazza MHSH, Maluf MLF, Consolaro MEL, Shinobu CS, Svidzinski TIE, Batista MR. Caracterização de leveduras isoladas da vagina e sua associação com candidíase vulvovaginal em duas cidades do Sul do Brasil. Rev Bras Ginecol Obstet [Internet]. 2005 Feb; 27(2): 58-63. Available from: <http://www.scielo. br/pdf/rbgo/v27n2/24297.pdf>. doi: http://dx.doi.org/10.1590/ s0100-72032005000200003
21. Gygax SE, Vermitsky JP, Chadwick SG, Self MJ, Zimmerman JA, Mordechai $E$, et al. Antifungal resistance of Candida glabrata vaginal isolates and development of a quantitative reverse transcription-PCR-based azole susceptibility assay. Antimicrob Agents Chemother [Internet]. 2008 Sep; 52(9): 3424-6. Available from: <http://aac.asm.org/content/52/9/3424.full. pdf\#page=1\&view=FitH $>$. doi: http://dx.doi.org/10.1128/ AAC.00462-08. PubMed PMID: 18591262. PubMed Central PMCID: PMC2533493.

22. Schaller M. Candida albicans-interactions with the mucosa and the immune system. J Dtsch Dermatol Ges [Internet]. 2006 Apr; 4(4): 328-36. Available from: <http://onlinelibrary.wiley.com/ doi/10.1111/j.1610-0387.2006.05935.x/pdf>. doi: http://dx.doi. org/10.1111/j.1610-0387.2006.05935.x

23. Barrenetxea Z. Vulvovaginitis candidiasica. Rev Iberoam Micol [Internet]. 2002; 19(1): 22-4. Available from: <http://www. reviberoammicol.com/2002-19/022024.pdf>.

24. Parazzini F, Di Cintio E, Chiantera V, Guaschino S. Determinants of different Candida species infection of the genital tract in women. Sporachrom study Group. Eur J Obstet Reprod Biol [Internet]. 2000; 93(2): 141-5. Available from: <http:// europepmc.org/abstract/MED/11074134>. doi: http://dx.doi. org/10.1016/S0301-2115(00)00289-X

25. Baldim IM, Pereira MA, Rufino RLA, Oliveira NMS, Fiorini JE. Teste de sensibilidade ao quefir de cepas de Candida spp. isoladas de vulvovaginites. Rev Ciênc Farm Básica Apl [Internet]. 2012; 33(3): 379-383. Available from: <http://serv-bib.fcfar.unesp.br/ seer/index.php/Cien_Farm/article/viewFile/2078/1263>

26. Toloi MRT, Candido RC, Franceschini SA. Vaginal candidiasis: risk factors. Rev Chil Cienc Méd Biol [Internet]. 2001; 11(1): 11-4.

27. Holanda AAR, Fernandes ACS, Bezerra CM, Ferreira MAF, Holanda MRR, Holanda JCP, et al. Candidíase vulvovaginal: sintomatologia, fatores de risco e colonização anal concomitante. Rev Bras Ginecol Obstet [Internet]. 2007 Jan; 29(1): 3-9. Available from: <http://www.scielo.br/pdf/rbgo/v29n1/a02v29n1.pdf>. doi: http://dx.doi.org/10.1590/S0100-72032007000100002

28. Colombo AL, Nucci $M$, Park BJ, Nouér SA, Arthington-Skaggs B, da Matta DA, et al. Epidemiology of candidemia in Brazil: a Nationwide sentinel surveillance of candidemia in eleven medical centrs. J Clin Microbiol [Internet]. 2006 Aug; 44(8): 2816-23. Available from: <http://jcm.asm.org/content/44/8/2816.long>.

29. Bassetti M, Ansaldi F, Nicolini L, Malfatto E, Molinari MP, Mussap $M$, et al. Incidence of candidemia and relationship with fluconazole use in an intensive care unit. J Antimicrob Chemother. 2009 Sep; 64(3): 625-9. Available from: <http:// jac.oxfordjournals.org/content/64/3/625.full.pdf>. doi: http:// dx.doi.org/10.1093/jac/dkp251 
30. Spinillo A, Capuzzo E, Gulminetti R, Marone P, Colonna L, Piazzi $G$. Prevalence of and risk factors for jungal vaginitis caused by non-albicans species. Am J Obstet Gynecol [Internet]. 1997 Feb; 176(1): 138-41. Available from: < http://www.ajog.org/ article/S0002-9378(97)80026-9/abstract>. doi: http://dx.doi. org/10.1016/S0002-9378(97)80026-9

31. Simões JA. Sobre o diagnóstico da candidíase vaginal. Rev Bras Ginecol Obstet [Internet]. 2005 May; 27(5): 233-4. Available from: <http://www.scielo.br/pdf/rbgo/v27n5/25637.pdf>. doi: http://dx.doi.org/10.1590/S0100-72032005000500001

32. Lopes-Consolaro ME, Albertoni T, Yoshida C, Mazucheli J, Peralta RM, Svidzinski TI.. Correlation of candida species and symptoms among patients with vulvovaginal candidasis in Maringa Paraná, Brasil. Rev Iberoam Micol [Internet]. 2004 Dec; 21(4): 202-5. Available from: < http://www.ncbi.nlm.nih.gov/ pubmed/15709802>

33. Corrêa PR, David PRS, Peres NP, Cunha KC, Almeida MTG. Caracterização fenotípica de leveduras isoladas da mucosa vaginal em mulheres adultas. Rev Bras Ginecol Obstet [Internet]. 2009; 31(4): 177-81. Available from: <http://www.scielo.br/ pdf/rbgo/v31n4/04.pdf>. doi: http://dx.doi.org/10.1590/S010072032009000400004

34. Sá MCN, Sousa HR, Amaro CSO, Pinheiro DN, Oliveira MMM, Pinheiro MCN. Isolamento de Candida no esfregaço cérvicovaginal de mulheres não gestantes residentes em área ribeirinha do Estado do Maranhão, Brasil, 2012. Rev Pan-Amaz Saude [Internet]. 2014 Mar; 5(1): 25-34. Available from: <http:// scielo.iec.pa.gov.br/scielo.php?script=sci_arttext\&pid=\$2176$62232014000100003 \& \operatorname{lng}=p t>$.

35. Andrioli JL, Oliveira GSA, Barreto CS, Sousa ZL, Oliveira MCH, Cazorla IM, et al. Frequência de leveduras em fluido vaginal de mulheres com e sem suspeita clínica de candidíase vulvovaginal. Rev Bras Ginecol Obstet [Internet]. 2009 Jun; 31(6): 300-4. Available from: <http://www.scielo.br/pdf/rbgo/v31n6/06.pdf>. doi: http://dx.doi.org/10.1590/S0100-72032009000600006

36. Rosa MI, Rumel D. Fatores associados à candidíase vulvovaginal: estudo exploratório. Rev Bras Ginecol Obstet [Internet]. 2004 Jan/Feb; 26(1): 65-70. Available from: <http://www.scielo.br/ pdf/rbgo/v26n1/19547.pdf>. doi: http://dx.doi.org/10.1590/ S0100-72032004000100010

37.Ota C, Unterkircher C, Fantinato V, Shimizu MT. Antifungical activity of propolis on different species of candida. Mycoses [Internet]. 2001 Nov; 44(9-10): 375-8. Available from: < http://onlinelibrary. wiley.com/doi/10.1046/j.1439-0507.2001.00671.x/abstract>. doi: http://dx.doi.org/10.1046/j.1439-0507.2001.00671.x
38. Longhini R, Raksa S M, Oliveira ACP, Svidzinski TIE, Franco SL. Obtenção de extratos de própolis sob diferentes condições e avaliação de sua atividade antifúngica. Rev bras farmacogn [Internet]. 2007 Sep; 17(3): 388-95. Available from: <http:// www.scielo.br/scielo.php?script=sci_arttext\&pid=S0102695X2007000300015\&lng=en>. doi: http://dx.doi.org/10.1590/ S0102-695X2007000300015

39. Monzote L, Cuesta-Rubio O, Campo FM, Márquez HI, Fraga J, Pérez Kl, et al. In vitro antimicrobial assessment of Cuban propolis extracts. Mem Inst Oswaldo Cruz [Internet]. 2012 Dec; 107(8): 978-84. Available from: <http://www.scielo.br/pdf/ mioc/v107n8/03.pdf>. doi: http://dx.doi.org/10.1590/S007402762012000800003

40. Kujumgiev A, Tsvetkova I, Serkedjieva Y, Bankova V, Christov R, Popov S. Antibacterial, antifungal and antiviral activity of propolis of different geographic origin. J Ethnopharmacol [Internet]. 1999 Mar; 64(3): 235-40. Available from: <http:// www.ncbi.nlm.nih.gov/pubmed/10363838>. doi: http:// dx.doi.org/10.1016/S0378-8741(98)00131-7. PubMed PMID: 10363838.

41. Negri M, Salci TP, Shinobu-Mesquita CS, Capoci IR, Svidzinski TI, Kioshima ES. Early state research on antifungal natural products. Molecules [Internet]. 2014 Mar; 19(3): 2925-56. Available from: <http://www.mdpi.com/1420-3049/19/3/2925>. doi: http://dx.doi.org/10.3390/molecules19032925. PubMed PMID: 24609016

42. Quintero-Mora ML, Londoño-Orozco A, Hernández-Hernández F, Manzano-Gayosso P, López-Martínez R, Soto-Zárate Cl. Efecto de extratos propóleos mexicanos de Apis mellifera sobre el crecimiento in vitro de Candida albicans. Rev Iberoam Micol [Internet]. 2008; 25(1): 22-6. Available from: <http://www. reviberoammicol.com/2008-25/022026.pdf>

43. Dota KFD, Freitas AR, Consolaro MEL, Svidzinski TIE. A challenge for clinical laboratories: detection of antifungal resistance in Candida Species causing vulvovaginal candidiasis. Lab medicine [Internet]. 2011 Feb; 42(2): 87-93. Available from: <http://labmed. ascpjournals.org/content/42/2/87.full.pdf\#page=1\&view=FitH > . doi: http://dx.doi.org/10.1309/LMDFCA8YEZOMQULA

44. Dalben-Dota KF, Faria MG, Bruschi ML, Pelloso SM, LopesConsolaro ME, Svidzinski TI. Antifungical activity of propolis extract against yeast isolated from vaginal exudates. J Altern Complement Med [Internet]. 2010 Mar; 16(3): 28590. Available from: <http://online.liebertpub.com/doi/ abs/10.1089/acm.2009.0281>. doi: http://dx.doi.org/10.1089/ acm.2009.0281 
45. Tamura NK, Negri MFN, Bonassoli LA, Svidzinski TIE. Fatores de virulência de candida spp isoladas de cateteres venosos e mãos de servidores hospitalares. Rev Soc Bras Med Trop [Internet]. 2007 Jan/Feb; 40(1): 91-3. Available from: <http://www. scielo.br/pdf/rsbmt/v40n1/a21v40n1.pdf>. doi: http://dx.doi. org/10.1590/S0037-86822007000100021

46. Sousa RP, Lopes $M E$, editors. Eficácia in vivo de diferentes formulas farmacêuticas de propolis em infeccção vaginal por Candida sp em comparação com nistatina e fluconazol. Anais do XIX EAIC; 2010 Oct 28-30; Guarapuava, BR. Guarapuava: UNICENTRO; 2010.

47.Uzel A, Sorkun K, Onçağ O, Cogŭlu D, Gençay O, Salih B. Chemical compositions and antimicrobial activities of four different Anatolian propolis samples. Microbiol Res [Internet]. 2005; 160(2): 189-95. Available from: <http://www.sciencedirect. com/science/article/pii/S094450130500011X>. doi: http:// dx.doi.org/10.1016/j.micres.2005.01.002

\section{Comment on this article:}

\section{(f) [8) in $8+S$ P}

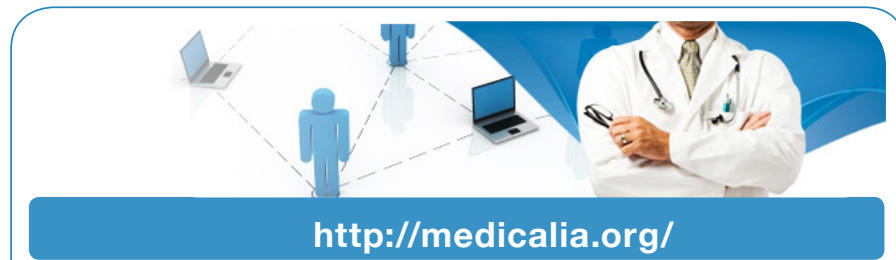

Where Doctors exchange clinical experiences, review their cases and share clinical knowledge. You can also access lots of medical publications for free. Join Now!

\section{Publish with iMedPub}

\section{http://www.imed.pub}

International Archives of Medicine is an open access journal publishing articles encompassing all aspects of medical science and clinical practice. IAM is considered a megajournal with independent sections on all areas of medicine. IAM is a really international journal with authors and board members from all around the world. The journal is widely indexed and classified Q1 in category Medicine. 